\title{
ОБРАЗЫ ПТИЦ НА СКАЛАХ ЖЕТЫСУ: К ПОСТАНОВКЕ ПРОБЛЕМЫ
}

\author{
(C) 2019 г. Б.А. Железняков
}

Наскальное искусство широко распространено по всему миру. В своей массе самыми распространенными в Евразии являются петроглифы эпохи бронзы, именно о них и пойдет речь в статье. Обычно в них мы видим животных, окружавших наших предков, зачастую с подчеркнутыми определенными признаками, например гипертрофированных размеров, с закрученными рогами, символизировавшими, например, (восходящее) солнце. Да и среди зооморфных образов выбирались особые, «встраиваемые» в мифологию. В Сибири и Центральной Европе относительно много изображений птиц. Жетысу к подобным регионам не относится. Однако отдельные изображения птиц известны, очевидно, что они были выбиты не случайно. Были ли они частью «картины мира» на крупных плоскостях или их самостоятельные (отдельные) изображения преследовали ритуальные или иные цели? Окончательного решения вопроса пока нет.

Ключевые слова: археология, памятники наскального искусства Жетысу, петроглифы, эпоха бронзы, образ птицы, солнечные повозки, охота

Образу птиц в наскальных изображениях региона Жетысу посвящено не так много исследований, прежде всего благодаря исключительной редкости его в петроглифах эпохи бронзы. Специальных исследований по этому лбразу пока не опубликовано. Этот образ достаточно редок в Европе, Ближнем и Среднем Востоке. И, наоборот, в определенной мере был более распространен в Сибири. Из 261 памятника наскального искусства Северной Азии, доступного для статистического анализа, на 256 отмечены изображения 1875 птиц, относящихся к разным эпохам [Чигаева, 2017, с. 16].

В Европе, где подавляющее число петроглифов относится к эпохе бронзы, этот образ ассоциирует- ся с представлением о возрождении жизни, особенно, это относится к водоплавающим птицам [Green, 1997, p. 204]. По мнению К. Кристиансена, известного исследователя наскального искусства и мифологии, именно водоплавающие птицы, чаще связки из трех лебедей, постепенно вытесняют упряжных лошадей для «солнечной лодки или повозки» (судна или транспорта с солярным божеством) - образ, который тиражировался на хорошо известных скандинавских бронзовых ножах. Эта смена в Северной Европе произошла в эпоху поздней бронзы. Также ученый приводит весьма распространенное европейское мифологическое представление о том, что солнце было доставлено с юга, точнее, из Греции в Скандинавию тремя 
лебедями [Kristiansen, 2018, p. 72], также относящееся к поздней бронзе. Известно множество легенд из ирландской, кельтской и иных мифологий относительно знаковых позиций птиц в них как предвестников переломных событий и постоянно сопровождавших божество или символизировавших божество. Лебеди имели особо тесное отношение к солярному божеству [Kristiansen, 2018, p. 71]. В местности Богуслан (Швеция, на границе с южной Норвегией) выбито множество изображений светила с отходящими во все стороны «трехпалыми отпечатками» от лап птиц, имитирующими лучи солнца (рис. 1).

Изображения птиц в Жетысу, например, стилизованных грифов иногда выбивались в сакскую эпоху: хорошо известны в Ешкиолмесе
[Байпаков, Марьяшев и др., 2005, с. 182], менее в Басбатыре [Железняков, Херманн, 2014, с. 36]. Сцены охоты с ловчими птицами были достаточно распространены в древнетюркское время, например в соседнем с известным ущельем Тамгалы отщелке «Сункарсай». Это может свидетельствовать о том, что в скифское время у птиц появляется ещё одна важная ипостась, которая постепенно становится доминирующей. Птицы выступают быстрокрылыми отважными хранителями силы и удачи, помощниками бесстрашных воинов [Чигаева, 2017, с. 11]. Вероятно, подходящими будут рассуждения анропологаэнциклопедиста Д.Н. Анучина: «Представления о птицах, как о существах способных быть носителями человеческих желаний и молений, a, с дру-

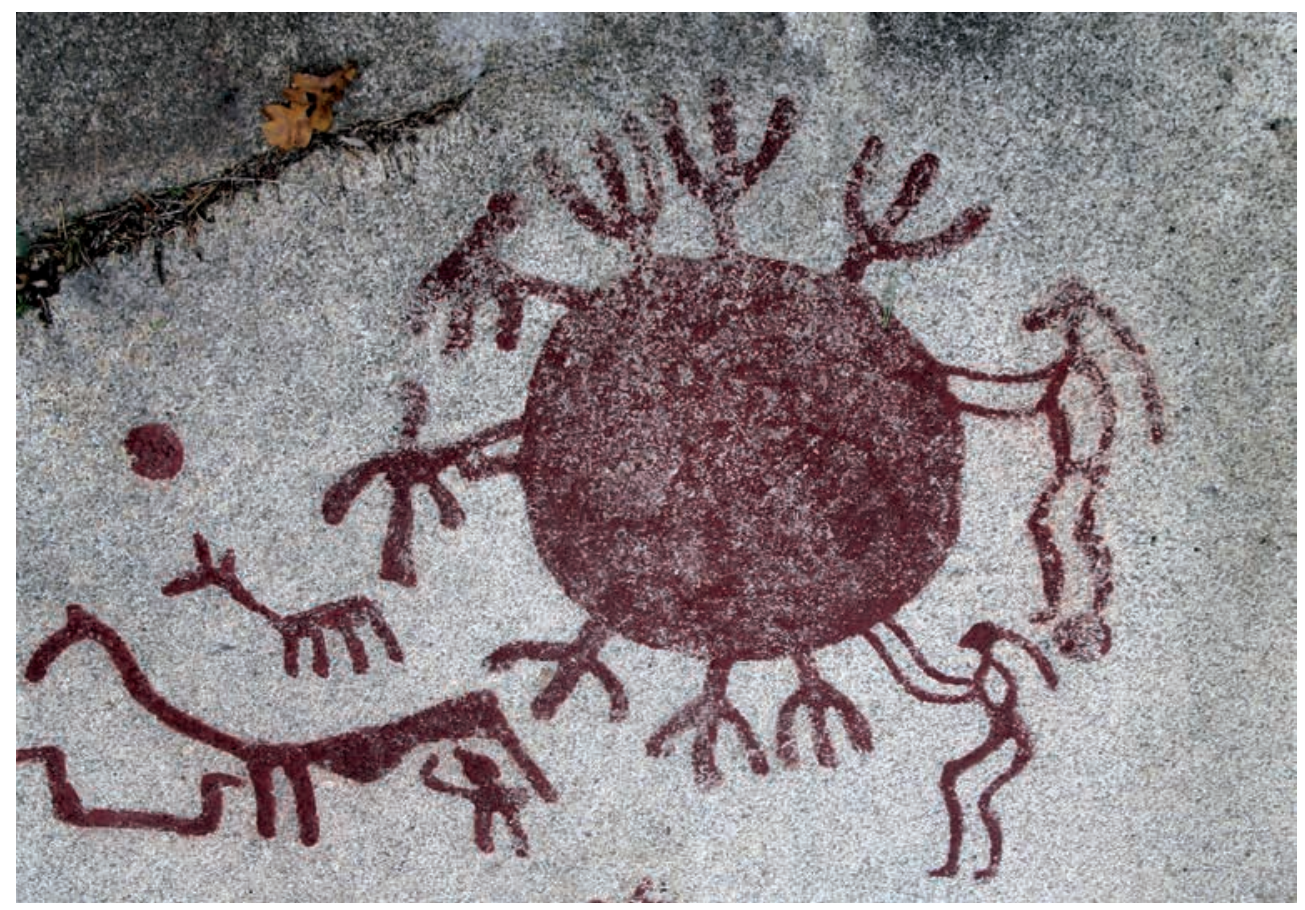

Рис. 1. Фото выбивки (прорисованной краской) солярного знака с «лапками» бинарной символикой лучей и лап птии. Эпоха бронзы. Танум (Аспебергет), Швеция. Фото автора

Fig. 1. Photo of carving (traced by paint) the solar sign with «pads»-binary symbolics of beams and paws of birds. Bronze Age. Tanum (Aspeberget), Sweden. Author's photo 
Железняков Б.А. Образы птиц на скалах Жетысу: к постановке проблемы

гой стороны, - возвестителями воли богов, символами их покровительства и объектами, служившими для воплощения в них божественной мощи, - такого рода представления мы встречаем у народов, стоящих на самых различных ступенях культуры, от дикарей-шаманистов до народов древнего Востока и Греции, и от варваров далёкой Азии и Африки до народных масс современной христианской Европы» [Чигаева, 2017, с. 12].

Изображения птиц в эпоху бронзы Жетысу единичны и не столь выразительны, как образы подчеркнуто выражавших идеологию животных. Возможно, что редкие изображения птиц в Жетысу чаще ассоциируются с притоком мигрантов, например из региона Южной Сибири, где подобных изображений значительно больше. Изображения птиц чаще, чем изображения зверей и связываются с шаманизмом, оборотничеством/териоморфизмом именно в тех регионах, где исследователи связывают изображения с шаманизмом [Pásztor, 2018, p. 193-194]. У нанайцев и ульчей птица упоминается как ездовое животное шамана - он улетал из загробного мира (буни - нан., були - ульч) верхом на птице поори [Окладников, 1972, c. 45]. Особая важность образа птицы не подвергается сомнению в сибирском шаманизме. Птица - это образ шамана, дух - помощник шамана. Костюм сибирского (и не только) шамана является олицетворением птицы и содержит орнитоморфную семантику. Возможно, что образы птиц были выбиты местным населением. В любом случае, это может быть связано с усилением миграционных процессов в эпоху поздней бронзы.

Интересные данные по изображениям птиц Центральной Европы можно почерпнуть в одном из по- следних сборников, посвященных, главным образом, европейскому шаманизму. В статье Э. Пастор (Emília Pásztor), посвященной именно образам птиц (в петроглифах и артефактах: в керамике, ювелирных изделиях), проведен анализ генезиса образа птиц в эпоху бронзы и в раннем железном веке в Карпатах, а также роли этого образа в истории культуры всей Евразии [Pásztor, 2018, p. 193-194]. В статье прослеживается связь населения Карпат с населением другими регионами Европы, а также с Сибирью, в том числе культурных параллелей регионов Южной Сибири и Венгрии [Pásztor, 2018, p. 195-197]. Раскрывается религиозная природа этого образа, фактически доказывается, что подавляющее большинство изображений птиц имеет связь с шаманизмом [Pásztor, 2018, p. 198-200].

Редкие на памятниках наскального искусства Жетысу изображения птиц, значительно проигрывают по своей художественной ценности и степени эмоционального воздействия, главным образам эпохи бронзы: быка, коня, архара и многих других. Птицы все-таки присутствуют среди всего многообразия наскальных образов Жетысу и, возможно, географически «объединяют» европейские и сибирские аналогии, где этих изображений значительно больше.

Опыт систематизации наскальных изображений с участием птиц в эпоху бронзы в Жетысу можно свести к трем композициям. Они выбивались как отдельные, самостоятельные изображения на плоскости, а также иногда в составе сцен охоты, где присутствуют два-три персонажа. Третий вариант: когда птицы небольших размеров изображаются на крупных (алтарных плоскостях) размерами более 1 м в длину наряду с животными и ан- 

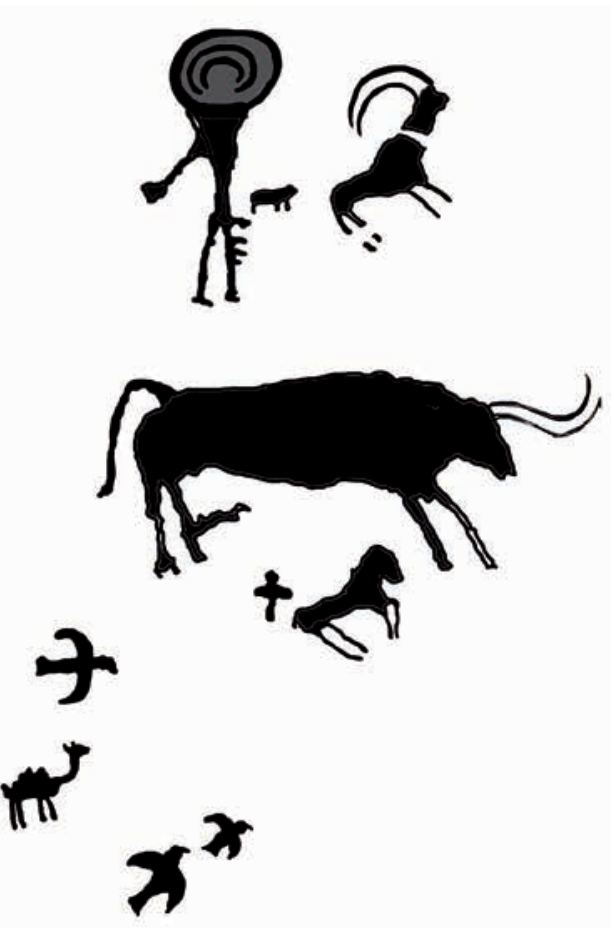

Рис. 2. Прорисовка плоскости с изображениями антропоморфного персонажа («луноголового») над быком, фоновыми животными и птицами (выполнена А.Б. Железняковым). Эпоха бронзы, Аккайнар

Fig. 2. The drawing of a carving of the panel with images of the anthropomorphous character ("lunar-head") over a bull,

background animals and birds (it is executed by A. Zheleznyakov). The Bronze Age, Akkaynar

тропоморными персонажами: (рис. 2) в Аккайнаре [Железняков и др., 2016, c. 108] и (рис. 3) в Кайши (Кайшы) [Железняков, 2017, с. 112].

В публикациях освещались вопросы хронологии (поздняя бронза), a также интерпретации. Несмотря на значительные размеры каменных плоскостей, изображения птиц на них не превышают 5-8 см в длину. Это свидетельствует об ограниченности их роли и влияния в мировоззрении населения региона в эпоху бронзы.
Изображение в Кулжабасы явно крупной и, возможно, водолавающей птицы (лапки не изображены, поскольку ниже уровня воды) [Садуакасулы и др., 2017, с. 132] (рис. 4), скорее всего, указывает на то, что передняя часть птицы отличается по выбивке. В первую очередь, это интерпретируется как отличие по цвету от ее крыльев и головы. Внимание к деталям птицы, а главное, нахождение ее выбивки вместе с изображениями отражающих «солярных» дисков, также небольших размеров (до 10 см), по-видимому, го-

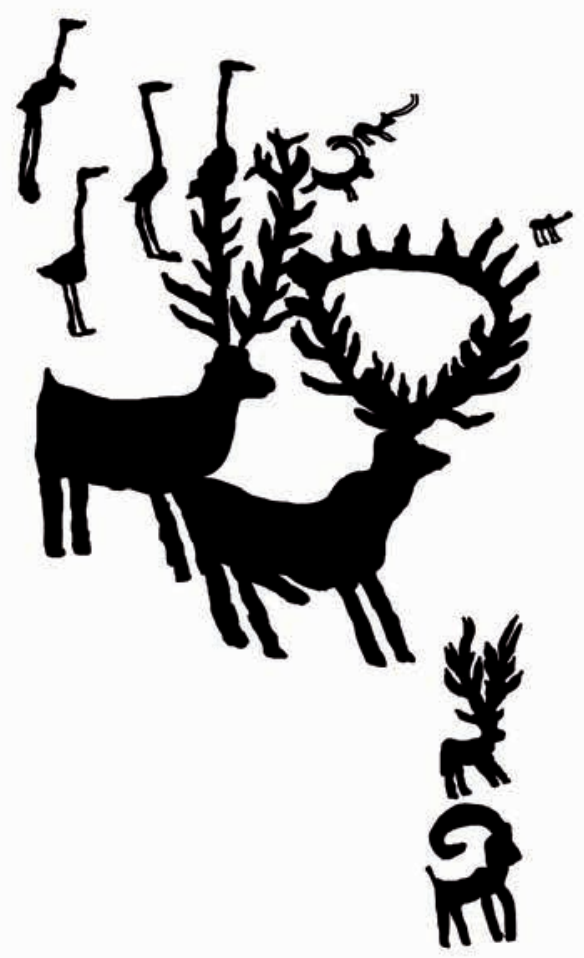

Рис. 3. Прорисовка плоскости с парой крупных оленей, фоновыми животными и птицами (выполнена А.Б. Железняковым). Эпоха поздней бронзы, Кайши

Fig. 3. The drawing of a carving of the panel with couple of large deer, background animals and birds (it is executed by $A$. Zheleznyakov).

The Late Bronze Age, Kayshi 
Железняков Б.А. Образы птиц на скалах Жетысу: к постановке проблемы

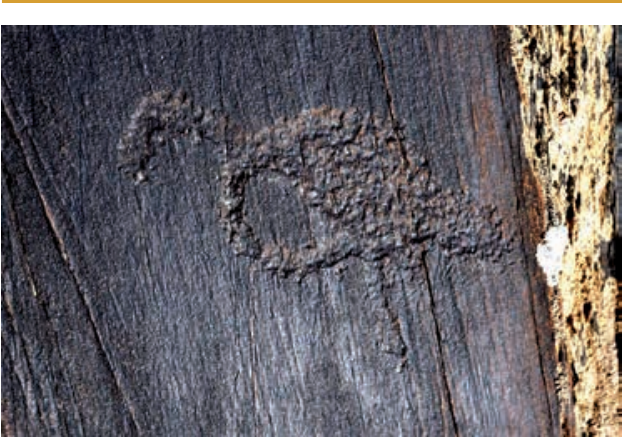

Рис. 4. Изображение крупной (водоплавающей) птицы.

Эпоха поздней бронзы, Кулжабасы

Fig. 4. The image of a big (natatorial) bird.

The Late Bronze Age, Kuljabasy

ворит о том, что птица приближается к максимальному своему влиянию в мировоззрении населения региона, по-видмому, в позднюю бронзу.

Стоит отметить, что интерпретации «солнца с птичьими лапками» зачастую весьма близка к «солнцу, сопровождаемому птицами» и/или «солнечному диску», размещенному на конской упряжи, известной как «солнечной повозки». Это можно видеть по прорисовкам, скомпонованным в экспозиции музея наскального искусства Танум (Швеция) и по комментариям его директора Г. Милстро (рис. 5).

Особенно большое количество изображений отмечается в Аккайнаре. Именно здесь, помимо «безобидных» сцен с «парящими» и «сидящими» птицами, выбито изображение крупной хищной птицы [Херманн, 2016, c. 68], победившей человека (рис. 6).

Локально расположены и не публиковавшиеся до сих пор изображения крупных птиц, похожих на страусов или из семейства дрофовых (рис. 6-8).

Определенные

аналогии птицам Аккайнара можно найти в рисунках Арал-Толгоя (Алтай), которые были опубликованы В.Д. Кубаревым, Д.В. Черемисиным. Однако значительно различаются манеры. На Алтае, по мнению авторов публикации: «это одинаковая трактовка тел птиц из Арал-Толгоя в виде яйцевидного овала, а также присутствие рядом с ними или даже внутри абрисов фигур, специально выбитых углублений, округлой или овальной формы, (символов яйца?)» [Кубарев, Черемисин, 1984, c. 93]. Несколько различаются и подходы к хронологии изображений. Алтайские изображения авторами публикации признается логичным

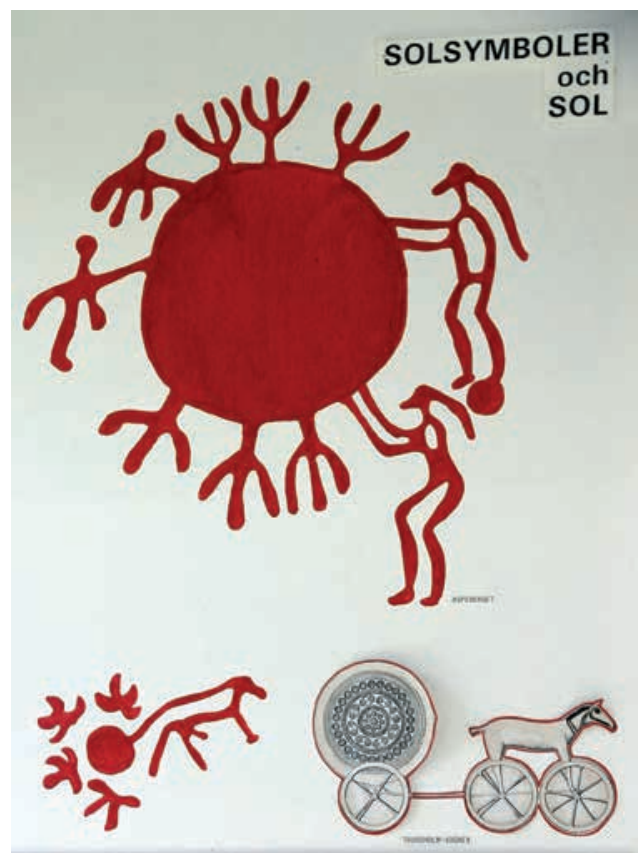

Рис. 5. Прорисовки наскальных изображений: солнце с «птичьими лапками», солнце, несомое небесным/ солнечным конем в сопровождении птии, а также артефакта из Трундхольма - «солнечная повозка». Экспозииия музея Танум.

Эпоха бронзы. Фото автора

Fig. 5. The drawing of a carving: of the sun with "bird's pads" the sun, borne a heavenly/solar horse accompanied by birds - "the solar vehicle" and also an artifact from Trundholm: The Bronze Age. Author's photo 


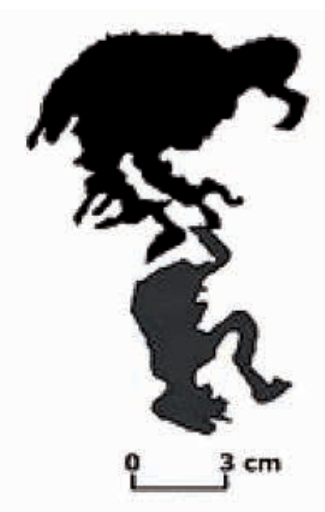

Рис. 6. Прорисовка петроглифа крупной хищной птицы и убитого ею (?) человека (выполнена Л. Херманном).

Эпоха поздней бронзы, Аккайнар

Fig. 6. The drawing of a carving of a large bird of prey and the person killed by it (?)

(executed by L. Herrmann). The Late Bronze Age, Akkaynar

датировать эпохой бронзы, при этом не исключается и более ранняя их датировка [Кубарев, Черемисин, 1984, с. 91-95]. Датировку птиц из Аккайнара логично сузить до поздней бронзы.

В ходе обследования окрестностей горы Майтобе (доминирующая вершина в Кастекском хребте Иле Алатау), расположенной в Жамбылском районе Алматинской области, на вновь открытом в 2015 г. памятнике наскального искусства Майтобе [перовое краткое сообщение об этом: $\mathrm{Ca}-$ дуакасулы, Железняков, 2016, с. 10] было обнаружено небольшое прочерченное на поверхности камня изображение крупной птицы типа журавля, которое предварительно также датировалось поздней бронзой. Его датировка достаточно условна, поскольку прямых аналогов этому изображению нет. Изображение птицы прочерчено на поверхности гранита. Достаточно удачно переданы тонкие и длинные ноги с лапками, голова (с хохолком и клювом) на длинной шее, пышное оперение хвоста. Крылья птицы переданы в расправленном состоянии, ноги соединены вместе. Птица передана в достаточно динамичной позе. Особенно, если учитывать предполагаемое время нанесения изображения - поздняя бронза. От птицы (шеи и верха головы) к некой фигуре - охотника (?) (чуть выше ее центра), находящейся слева от птицы, переданной весьма схематично вертикальными чертами, прочерчены две линии, которые можно интерпретировать как веревку или петлю (силки), накинутую на эту птицу. Фигурка птицы около 6 см высотой, человека - менее 5 см (рис. 10, 11). Тем самым, это изображение, несмотря на всю схематичность образа человека (?), можно интерпретировать как сцена поимки крупной птицы охотником. Это изображение небольших размеров выполнено в технике граффити. И это отличает его от предыдущих, выбитых изображений.

Тем самым можно констатировать, что весьма незначительное число изображенных на скалах Жетысу птиц связано с тем, что большинство явно шаманских или жреческих изображений связано с традицией обращения служителей культа в образ животного: волка, козла и других, но не птиц. Например, на таком значительном памятнике как Кулжабасы, где общее количество петроглифов составляет около 15 тыс., известно около пяти изображений птиц. На соседнем памятнике: Аккайнаре из 18 птиц - пять относится к эпохе бронзы, две к сако-усуньскому времени и 11 - к древнетюркскому времени [Херманн, 2016, с. 59]. К сожалению, на большинстве памятников наскального искусства Жетысу полный статистический анализ пока не проведен. 
Железняков Б.А. Образы птиц на скалах Жетысу: к постановке проблемы
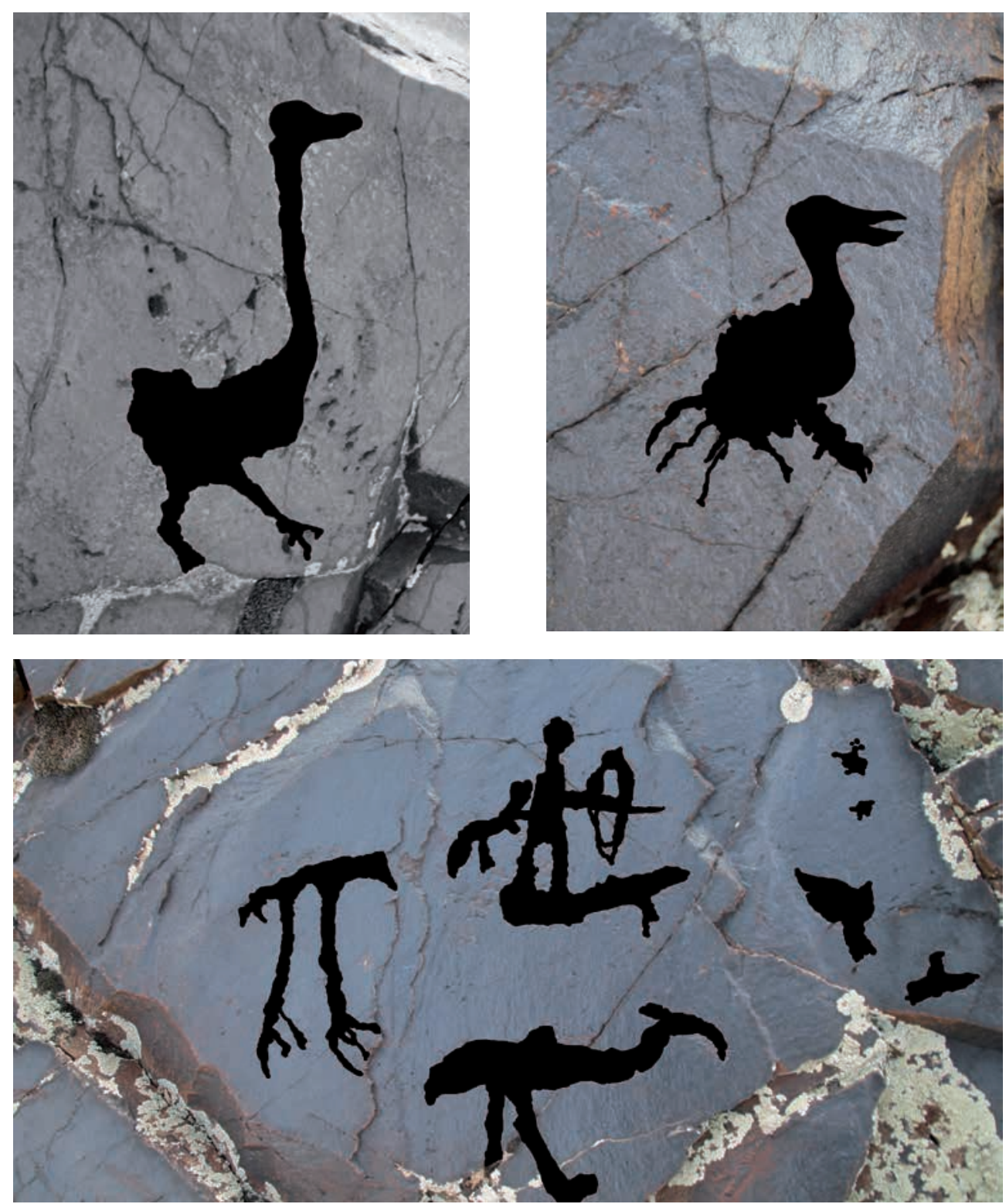

Рис. 7-9. Прорисовки крупных птии (страусов или из семейства дроф?). Эпоха поздней бронзы, Аккайнар. Выполнены А. Железняковым на фото Л. Херманна

Fig. 7-9. The drawing of a carvings of birds (ostriches or from family of bustards?). The Late Bronze Age, Akkaynar. Executed by A. Zheleznyakov on L. Herrmann's photo

Тем не менее, общая тенденция достаточно очевидна, от эпохи бронзы к средним векам процентное содержание образа птицы значительно растет. Это происходит, в том числе и за счет того, что роль птиц в материальной и духовной жизни у населения региона Жетысу возрастает. 


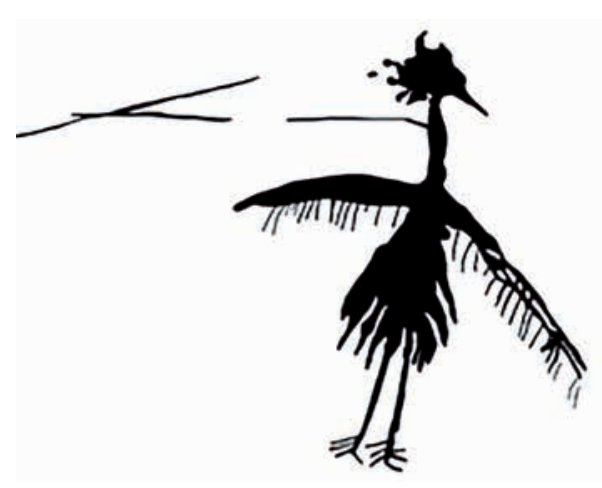

Рис. 10, 11. Прорисовка и фото крупной птицы (журавля?) и человека с петлей (?), сиена охоты.

Эпоха поздней бронзы, Майтобе

Fig. 10, 11. The drawing and photo of the carving of large bird (crane?) and the person with a loop (?), a scene of hunting. The Late Bronze Age, Maytobe

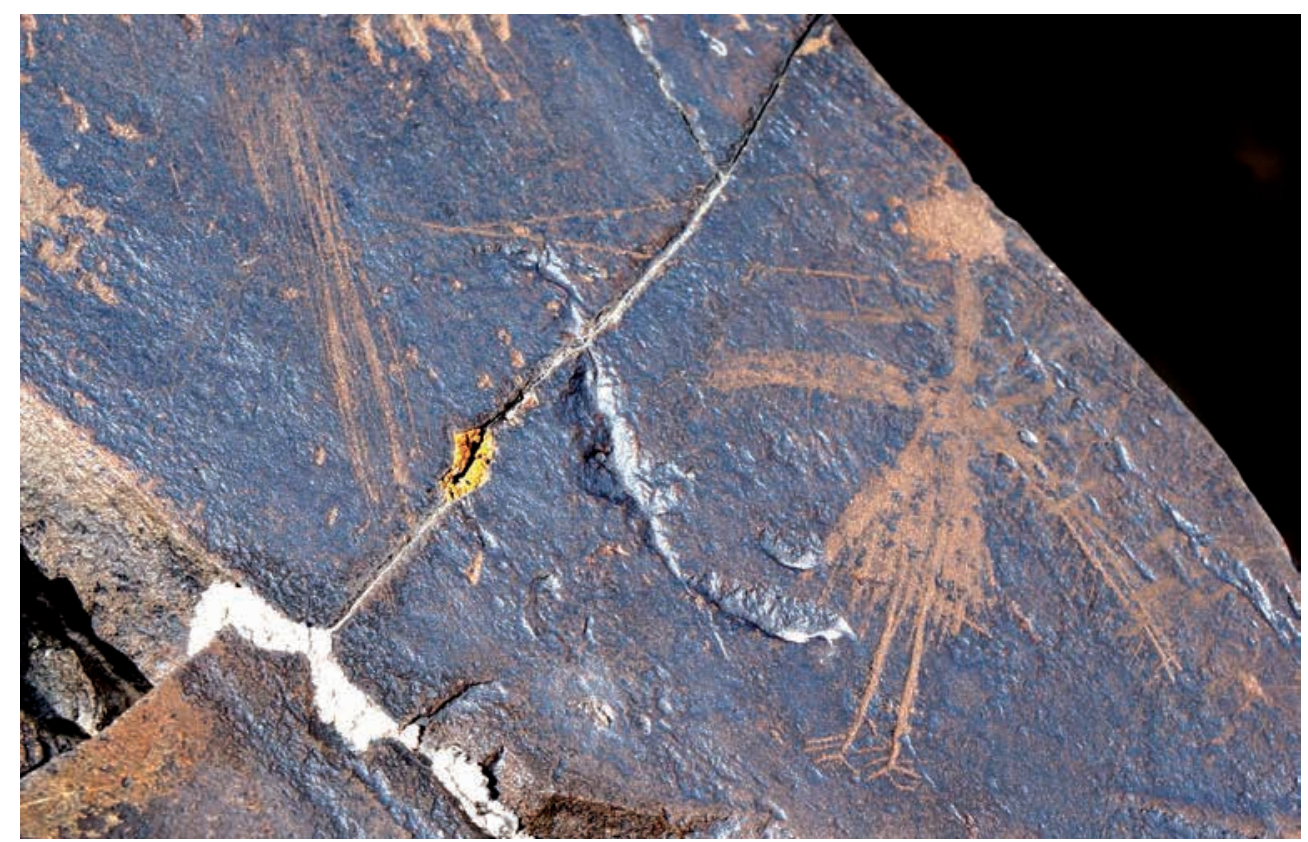

ЛИТЕРАТУРА

1. Байпаков К.М., Марьяшев А.Н., Потапов С.А., Горячев А.А. Петроглифы в горах Ешкиольмес. Алматы, 2005. 226 с.

2. Железняков Б.А. Алтарные наскальные композиции с оленями Жетысу (Кайши, Актерек) // История и археология Семиречья. Алматы, 2017. Вып. 5. С. 111-126.

3. Железняков Б.А., Херманн Л. Петроглифы Басбатыра // Известия МОН РК. Сер. обществ. и гуманит. наук. 2014. № 5 (297). С. 30-39.

4. Железняков Б.А., Садуакасулы А., Херманн Л. Новые петроглифы Тамгалы и Чу-Или // Древности Жетысу. Памятники археологии Жамбылского района: сб. научн. ст. Алматы, 2016. С. 88-109.

5. Кубарев В.Д., Черемисин Д.В. Образ птицы в искусстве ранних кочевников Алтая // Археология юга Сибири и Дальнего Востока. Новосибирск: Наука, 1984. C. 87-99.

6. Окладников А.П. Центрально-азиатский очаг первобытного искусства, Новосибирск., $1972.88 \mathrm{c.}$

7. Садуакасуль А., Железняков Б.А. История изучения историко-культурного наследия Жамбылского района // Древности Жетысу. Памятники археологии Жамбылского района: сб. научн. ст. Алматы, 2016. С. 3-18. 
Железняков Б.А. Образы птиц на скалах Жетысу: к постановке проблемы

8. Садуакасуль А., Железняков Б.А., Херманн Л. Наскальное искусство хребта Кулжабасы. Алматы, 2017. 240 с.

9. Соломатина B.B. Образ птицы в шаманизме народов дальнего востока // Научное сообщество студентов XXI столетия. Общественные науки: сб. ст. по мат. XV междунар. студ. науч.-практ. конф. № 15. Новосибирск, 2013. С. 37-41.

10. Херманн Л. Наскальное искусство местности Аккайнар // Древности Жетысу.

Памятники археологии Жамбылского района: сб. научн. ст. Алматы, 2016. С. 52-72.

11. Чигаева В.Ю. Образы птиц в наскальном искусстве Северной Азии: дис. ... канд. ист. наук. Кемерово, 2007. 174 с.

12. Green, M.A. Dictionary of Celtic Myth and Legend. London, 1997. 576 p.

13. Kristiansen $K$. The winged triad in Bronze Age symbolism: birds and their feet // Future Essays in Archaeology and Rock Art Studies in Honour of Dr. Phil. h.c. Gerhard Milstreu. Ed. by James Dodd \& Ellen Meijer. Oxford, 2018. P. 70-75.

14. Pásztor P. Comments on Bird Symbolism of the Bronze Age Carpathian Basin and its Possible Relationship with Shamanism // Archaeological Approaches to Shamanism: Mind-Body, Nature, and Culture. Cambridge, 2018. P. 193-209.

Сведения об авторе:

Железняков Борис Анатольевич - докторант, Институт археологии им. А.Х. Маргулана (г. Алматы, Казахстан); boriszheleznyakov@mail.ru

\section{ЖЕТІСУ ЖАРТАСТАРЫНА САЛЫНҒАН ҚҰСТАРДЫН БЕЙНЕСІ: МӘСЕЛЕНІҢ ҚОЙЫЛЫМЫ}

\section{Б.А. Железняков}

Жартас өнері әлем бойынша кеңінен таралған. Өзінің саны жағынан Еуразияда көп тарағаны қола дәуірінің петроглифтері болып табылатындықтан, мақалада осы мәселе сөз болады. Олардан ата-бабаларымызды қоршаған ортадағы жануарларды жиірек көреміз, көбіне олар белгілі бір белгілермен сызылған, мысалы, қалыптан тыс көлемі ұлғайтылған, бұратылған мүйіздер күн символын (көтеріліп шыққан күн) білдіреді. Жануарлардың арасынан қазіргі мифологиялық бейнелермен байланысты ерекше түрлерін де кездестіруге болады. Бірқатар аймақтарда: Сібір, Орталық Еуропада салыстырмалы түрде құс бейнелері көп. Жетісу мұндай аймаққа жатпайды. Дегенмен, жекелеген құс бейнелері кездеседі, бірақ олардың кездейсоқ соғылмағандығын көруге болады. Бұл «әлем көрінісінің» бір бөлігі немесе не ғұрыптық, не басқа да мақсатта болды ма екен? Осы сұрақтың нақты шешімі әзірге жоқ.

Түйін сөздер: археология, Жетісу жартас өнерінің ескерткіштері, петроглифтер, қола дәуірі, құс бейнесі, күн арбасы, аңшылық

\section{IMAGES OF BIRDS IN JETYSU'S ROCKS ART SITES: TO STATEMENT OF THE PROBLEM}

\section{B.A. Zheleznyakov}

Petroglyphic art is widespread worldwide. Images of rock art of the Bronze Age is the most widespread in Eurasia in general and the article is devoted to this chronological frames. Most often between them we see the animals surrounding our ancestors, is frequent with emphasized certain signs, for example the hypertrophied sizes, the twirled horns symbolizing (ascending) sun. Among animals the special types which are embed in in modern to images mythology were chosen. In such regions as Siberia or Central Europe, relatively there are a lot of images of birds. Jetysu region doesn't treat to similar. However separate images of birds are available, it is obvious that they have been carved not accidentally. 
Whether it was a part of "a world picture" or pursued ritual or other aims? There is no final decision of a question yet.

Keywords: archaeology, sites of rock art of Jetysu, petroglyphs, the Bronze Age, the image of a bird, solar chart, hunting

\section{REFERENCES}

1. Baypakov K.M., Mar'yashev A.N., Potapov S.A., Goryachev A.A. 2005. Petroglify $v$ gorah Eshkiol'mes (Petroglyphs in the mountains of Eshkiolmes). Almaty (in Russian).

2. Zheleznyakov, B. A. 2017. In Istoriya i arheologiya Semirech'ya (History and archeology of Semirechye) 5, 111-126 (in Russian).

3. Zheleznyakov, B. A., Hermann, L. 2014. In Izvestiya MON RK, ser. obshchestv. $i$ gumanit. nauk (News MES RK. Ser. societies and humanity of sciences), 5 (297), 30-39 (in Russian).

4. Zheleznyakov, B. A., Saduakasuly, A., Hermann, L. 2016. In Drevnosti Jetysu. Pamyatniki arheologii Jambylskogo rajona (Antiquities Jetysu. Monuments of archaeology of Jambyl region). Almaty 88-109 (in Russian).

5. Kubarev, V. D., Cheremisin, D. V. 1984. In Arheologiya yuga Sibiri i Dal'nego Vostoka (Archeology of the south of Siberia and the Far East). Novosibirsk: "Nauka" Publ., 87-99 (in Russian).

6. Okladnikov A.P. Central'no-aziatskij ochag pervobytnogo iskusstva (Central Asian center of primitive art). Novosibirsk 1972 (in Russian).

7. Saduakasuly, A., Zheleznyakov, B. A. 2016. In Drevnosti Jetysu. Pamyatniki arheologii Jambylskogo rajona (Antiquities Jetysu. Monuments of archaeology of Jambyl region). Almaty, 3-18 (in Russian).

8. Saduakasuly, A., Zheleznyakov, B. A., Hermann, L. 2017. Naskal'noe iskusstvo hrebta Kuljabasy (Rock art of the Kuljabasy range). Almaty (in Russian).

9. Solomatina V.V. 2013. In Nauchnoe soobshchestvo studentov XXI stoletiya (Scientific community of students of the XXI century), 15, 37-41 (in Russian).

10. Hermann, L. 2016. In Drevnosti Jetysu. Pamyatniki arheologii Jambylskogo rajona (Antiquities Jetysu. Monuments of archaeology of Jambyl region). Almaty 52-72 (in Russian).

11. Chigaeva, V. Yu. 2007. Obrazy ptic v naskal'nom iskusstve Severnoj Azii (The images of birds in the rock art of North Asia): thes. Cand. Diss. Kemerovo (in Russian).

12. Green, M.A. 1997. Dictionary of Celtic Myth and Legend. London.

13. Kristiansen, K. 2018. In Dodd, J., Meijer, E. (eds.) Future Essays in Archaeology and Rock Art Studies in Honour of Dr. Oxford, 70-75.

14. Pásztor, P. 2018. In Archaeological Approaches to Shamanism: Mind-Body, Nature, and Culture. Cambridge, 193-209.

About the Author:

Zheleznyakov Boris A. Doctoral Candidate, A.Kh. Margulan Archeology Institute, Almaty, Kazakhstan; boriszheleznyakov@mail.ru

\footnotetext{
Мүдделер қақтығысы туралы ақпаратты ашу. Автор мүдделер қақтығысының жоқтығын мәлімдейді. / Раскрытие информации о конфликте интересов. Автор заявляет об отсутствии конфликта интересов. / Disclosure of conflict of interest information. The author claim no conflict of interest.

Мақала туралы ақпарат / Информация о статье / Information about the article. Редакцияға түсті / Поступила в редакцию / Entered the editorial office: 08.10.2018. Рецензенттер мақұлдаған / Одобрено рецензентами / Approved by reviewers: 15.10.2018. Жариялауға қабылданды / Принята к публикации / Accepted for publication: 22.10.2018.
} 